\title{
名古屋市中心部における4d-GISを用いた 都市の経年変化によるMSFAに関する研究
}

\author{
青柳 淳之介 1 ・杉本 賢二 2 ・奥岡 $\quad$ 桂次郎 ${ }^{3}$ ・谷川 寛樹4 \\ 1学生会員 名古屋大学大学院環境学研究科 学生（†464-8601 名古屋市千種区不老町D2-1） \\ E-mail:junnosuke.aoyagi@gmail.com \\ 2正会員 名古屋大学大学院環境学研究科 特任講師（干464-8601 名古屋市千種区不老町D2-1） \\ E-mail:k.sugimoto@nagoya-u.jp \\ 3 正会員 名古屋大学大学院環境学研究科 助教 （广464-8601 名古屋市千種区不老町D2-1） \\ E-mail:okuoka@nagoya-u.jp \\ 4正会員 名古屋大学大学院環境学研究科 教授 （广464-8601 名古屋市千種区不老町D2-1） \\ E-mail:tanikawa@nagoya-u.jp
}

\begin{abstract}
建築物や道路などの社会基盤構造物を建設する際には大量の資材が投入されており，都市に蓄積された 物質は構造物が取り壊される際に廃棄される。このように大量の物質が移動する際には投入や廃葉処理を 効率的に行う必要があり, マテリアルフローを定量的に把握することは, 循環型社会の形成を考える上で 不可欠である. 本研究では，名古屋市の中心部をケーススタディ対象地として，1970年，1980年，1990年， 1997年，2003年，2009年の6年代で構築された4d-GISを用いて用途地域別や，大規模な建物更新があった エリアを対象にMSFA(Material Stock and Flow Analysis)を行った. その結果, 対象エリア内のマテリアルス トックは増加傾向にあり，特に商業地域において物質が高密度に分布していることが分かった。さらに, 用途地域などの都市構造の変化が物質代謝に影響を与えていることを示した.
\end{abstract}

Key Words: material stock, material flow, Geographic Information System, 4d-GIS, Nagoya

\section{1. はじめに}

経済活動には大量の資材の投入・廃棄が伴う。環境省 (2014） ${ }^{1)}$ によると，平成23年度の日本の総物質投入量 は15.7億トンであり，廃衰量は5.6億トンである. 廃棄量 のうち 2.4 億トンは循環利用されている。このように人 間活動には大量の物質移動が伴い，資材の採取から運搬, 投入，廃棄処理に至る各過程において環境への負荷が生 じている．また，我が国では高度成長期に大量に建設さ れた社会インフラがこの先耐用年数を迎え，多くの廃棄 物や建設副産物が発生する事が予想されており，それら を処理する機能も十分でないことから，都市における物 質の投入と排出といったマテリアルバランスの崩壊が危 惧されている．こうした将来のマテリアルバランスの変 化を予測し，適切な維持管理を行うためには，過去や現 在のマテリアルフローを定量的に把握するMSFA(Material Stock and Flow Analysis)が重要である. ${ }^{2)}$

MSFAに関する既往研究として先述の環境省（2014） ${ }^{1)}$
は，製造や輸出入に関する統計情報から，日本全国の分 析を行った. また， Hashimoto et al.(2007) $)^{3}$ は建設活動に関 わる統計情報をもとに日本国内のマテリアルストック ・ フローを分析した。 さらに, 長岡ら (2009） ${ }^{4}$ は建築 物・道路・下水道に関寸る統計資料から, 日本全国に蓄 積されている資材量を推計した。 このように，様々な統 計情報を用いることで日本全国や各都道府県におけるマ テリアルストック・フローの把握が可能である.

しかし，都市における物質循環の様子は，個々の都市 の成長や衰退といった変化と密接に関係しており, 都心 部からのアクセスの利便性や，山地なのか海沿いなのか といった地理的な特性や, 商業エリアや工業エリア, 住 居エリアといった都市構造の違いなどもマテリアルスト ック・フローの性質に影響を与えていると考えられる. そのため, 日本全国や都道府県などの比較的大規模なス ケールでの推計は, 全体の量を把握するためには有効で あるが，都市内部での発展度合いや地域性の違いによる マテリアルストック・フローへの影響を考慮することが 
できない. 都市の性質と物質循環との関連を詳細に分析 することで，今後ある地域の都市計画を遂行する際に， 将来の物質投入量, 廃棄量一の影響を定量的に予測し, 考慮することができる．また，現存都市の将来廃棄量を 推計して, 適切な廃棄物処理計画などに役立てることも 可能である. 都市におけるマテリアルストック・フロー と都市の性質にみられる関連を分析するためには, 行政 による土地利用規制である用途地域ごとの推計を行うこ とが有効である. 用途地域は全国で広く使用されている 点で汎用性もあり, 過去の履歴情報を得ることも比較的 容易である. 用途地域とマテリアルストック・フローの 関連を分析することにより，例えばある地域を住居地域 から商業地域に指定を変更することに伴う，今後生じる 物質移動の様子を予測することができる，それにより， 将来の都市におけるマテリアルバランスが適切に保たれ るように計画や維持管理を行うための指針となりうる.

GIS(Geographic Information System)により，一つ一つの建築 物や道路, 下水道や港湾施設などをデータベース化し, ボトムアップの推計を行うことで, 広範囲から詳細なエ リアまで，地理的な条件を考慮に入れた推計が可能とな る. また，経年のGISデータベースを使用して時系列で の分析をすることで，統計情報だけでは把握が困難な， ある期間における投入・廃棄などのマテリアルフローの 空間分布を推計することも可能である. このような時系 列の推計を行うために，4d-GIS と呼ばれる，様々な属性 情報や地理情報を持ち, さらに時間軸を加えたGISデー タベースが用いられる。4d-GISを用いたMSFAとして,

Tanikawa and Hashimoto（2009） 5)は，和歌山市とマンチェ スター市を対象に4d-GISを構築し，建築物や道路，鉄道 などのマテリルストック・フローや建築物の耐用年数を 推計した．また，谷川ら（2001）のは，北九州市におけ る経年データベースを構築し, 住宅地建設における総物
質必要量を推計した.

本研究では, 青柳ら (2014）》で構築された名古屋市

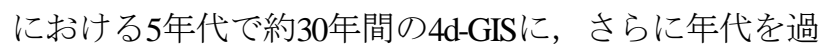
去に遡り，6年代で約40年間の4d-GISを構築してMSFAを 行った. さらに, 新たに 1 年代を加えたのみでなく, 各 建築物の建築面積や構造種別の推計により詳細な仮定を 設定するなどデータベースの改善を施した．さらに対象 年代間で用途地域の変更や大規模な建築物の変化があっ た区画を対象にMSFAを行い, 都市の構造とマテリアル ストック・フローの関連を分析した.

\section{2. 研究手法}

\section{（1）ケーススタディ対象区域}

本研究では, 図-1に示寸名古屋市の中心部の, JR名古 屋駅を西端, 栄地域を東端とした面積約 $12 \mathrm{~km}^{2}$ の区域を ケーススタディの対象とした. 図-1には2009年時の用途 地域を色分けして示している. また, 表-1に対象エリア 内の建築物棟数, 表-2に用途地域別に集計した合計延床 面積の変化をそれぞれ示す. 対象地域のうち南半分は商 業地域が占めており, 高層の商業ビルが多く存在する, 名古屋の中心街と言える活気のあるエリアである．また， 北半分は名古屋城を含む商業地域, 近隣商業地域, 準工 業地域, 第一種住居地域, 第二種住居地域が混在した地 域である. 対象エリアの用途地域は, 本研究で対象とし ている約40年の間では大きな変更はないものの, 一部で 用途地域が変更されたエリアもある. 変更されたエリア から3つのエリアを抽出して, 図-1中のAエリア, Bエリ ア, Cエリアとし, 各エリア内でのマテリアルストッ ク・フローの推移を推計した. 表-3に, 用途地域の変更 された年と変更内容を示す，また，甲エリア，乙エリア
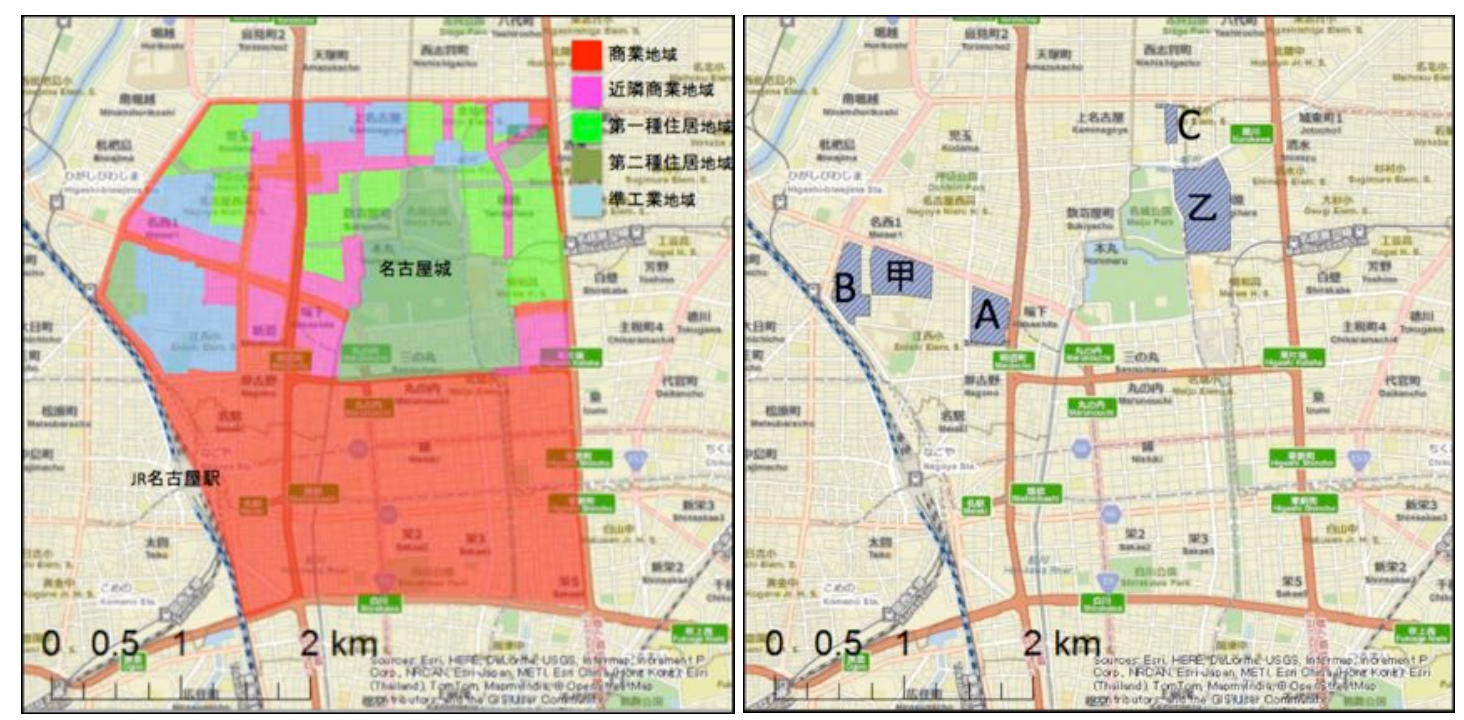

図-1 ケーススタディ対象区域（左-用途地域による色分け，右抽出エリア） 
表-1 用途地域別の建築物棟数

\begin{tabular}{c|c|c|c|c|c|c}
\hline & 1970 & 1980 & 1990 & 1997 & 2003 & 2009 \\
\hline \begin{tabular}{c} 
商業地域 \\
\hline $\begin{array}{c}\text { 近隣商業 } \\
\text { 地域 }\end{array}$
\end{tabular} & 14414 & 12143 & 11470 & 9941 & 13038 & 11974 \\
\hline $\begin{array}{c}\text { 第一種 } \\
\text { 住居地域 }\end{array}$ & 4185 & 3652 & 3645 & 3285 & 4612 & 4480 \\
\hline $\begin{array}{c}\text { 第二種 } \\
\text { 住居地域 }\end{array}$ & 1001 & 733 & 778 & 890 & 1397 & 1390 \\
\hline $\begin{array}{c}\text { 準工業 } \\
\text { 地域 }\end{array}$ & 4901 & 4521 & 4246 & 3197 & 4536 & 4383 \\
\hline 合計 & 28699 & 24700 & 23718 & 21072 & 28743 & 27077 \\
\hline
\end{tabular}

表-3 各エリアの変更内容

\begin{tabular}{l|l|l}
\hline & 変更年 & 変更内容 \\
\hline $\mathrm{A}$ エリア & 1994 年 & 商業地域 $\rightarrow$ 近隣商業地域 \\
\hline $\mathrm{B}$ エリア & 1994 年 & 準工業地域 $\rightarrow$ 第二種住居地域 \\
\hline $\mathrm{C}$ エリア & 1994 年 & 住居地域 $\rightarrow$ 近隣商業地域 \\
\hline 甲エリア & & 市営南押切荘建設 \\
\hline 乙エリア & & 市営城北団地建設 \\
\hline
\end{tabular}

では期間内にそれぞれ大規模な市営団地が建築されてお り，それぞれのエリアで集計することで，マテリアルス トックへの影響を推計した。

\section{（2）使用データ}

本研究で使用した4d-GISは，青柳ら（2014）7)で整備さ れた，1980年，1990年，1997年，2003年，2009年の5年代 のデータベースに，新たに1970年を追加したものである
表-2 用途地域別の合計延床面積 $\left(\mathrm{km}^{2}\right)$

\begin{tabular}{c|c|c|c|c|c|c}
\hline & 1970 & 1980 & 1990 & 1997 & 2003 & 2009 \\
\hline \begin{tabular}{c} 
商業地域 \\
\hline $\begin{array}{c}\text { 近隣商業 } \\
\text { 地域 }\end{array}$
\end{tabular} & 0.98 & 0.62 & 11.12 & 11.10 & 12.97 & 14.79 \\
\hline $\begin{array}{c}\text { 第一種 } \\
\text { 住居地域 }\end{array}$ & 0.82 & 0.77 & 0.92 & 0.85 & 1.21 & 1.27 \\
\hline $\begin{array}{c}\text { 第二種 } \\
\text { 住居地域 }\end{array}$ & 0.45 & 0.47 & 0.71 & 0.77 & 1.13 & 1.17 \\
\hline $\begin{array}{c}\text { 準工業 } \\
\text { 地域 }\end{array}$ & 0.90 & 0.81 & 1.02 & 0.78 & 1.11 & 1.20 \\
\hline 合計 & 10.57 & 12.63 & 15.01 & 14.80 & 17.85 & 19.88 \\
\hline
\end{tabular}

(図-2）。これらのデータベースは，エリア内の建築物 一棟一棟がポリゴンになっており，ゼンリンのZ-map ${ }^{8)}$ 住宅地図 ${ }^{9}$, 航空写真 ${ }^{10)}$ な゙゙をもとに構築されている. それぞれのポリゴンには様々な属性情報が付加されてお り，本研究で使用した属性情報は，「建物名称」「階数」 「建築面積」「構造種別」「用途地域」である. 以下に 詳細を説明する.

\section{a) 建物名称}

Z-map や住宅地図に記載されている建物名称を全てポ リゴンに付与した。

\section{b) 階数}

各建築物の階数は，Z-map や住宅地図に階数の記載が あるものはその值を使用した。記載のない場合は，当時 の航空写真などの資料から階数を決定した.

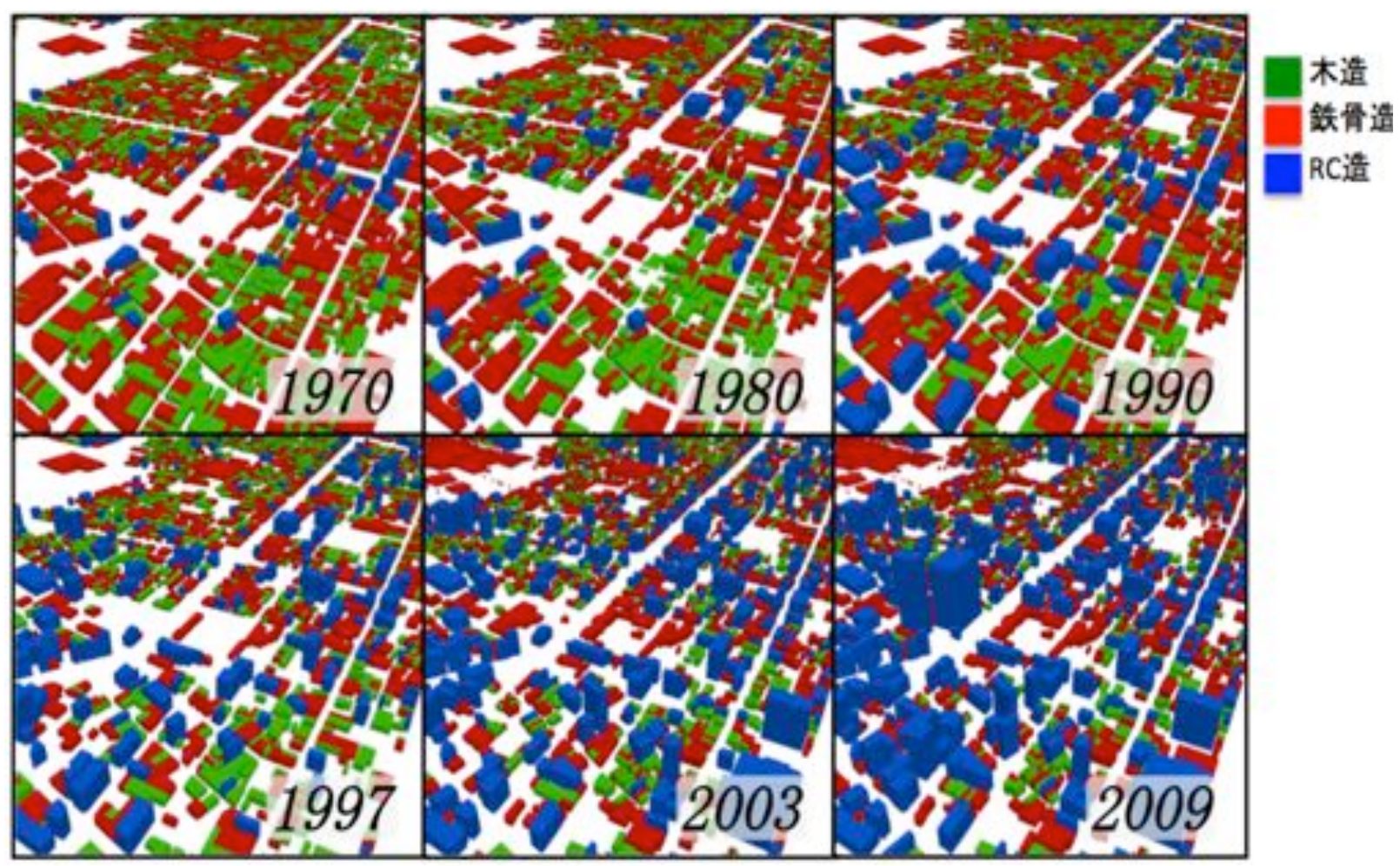

図-2 名古屋市中心部における 4d-GIS 一部拡大図 


\section{c）建築面積}

GIS のジオメトリ演算機能によって各ポリゴンの面積 を算出し，それを建築面積とした。ただし，1997 年以 前の住宅地図では, 所有敷地の形で建築物が表現されて いるため，ポリゴンの面積に修正を加えたものを建築面 積として仮定している，具体的には，ポリゴンの面積に その区画の建ぺい率を乗じたものを建築面積としている ただし，ケーススタディエリア内の商業地域の一部は防 火地域に指定されており，防火地域では建ぺ率の規制 が緩和されるため，建築物が敷地いっぱいまで立地して いると仮定し，敷地の面積の值をそのまま建築面積とし て採用している. また，ケーススタディエリア内には公 開空地を設けることで建ぺい率の規制が緩和されている 建築物も複数存在しており, それらについても同様に敷 地面積の值を建築面積として推計を行った.

また, 本研究では延床面積として建築面積と階数を乗 じた值を用いているが，一般的に，斜線制限やデザイン 上の理由から各階層が同一の形状でない建築物は多く, 建築面積と階数の積を集計した值が実際の合計延床面積 よりも大きな值となることがこれまでも指摘されている これまでに，大場（2000） ${ }^{11}$ は千葉県市川市を，阪田ら (2002) ${ }^{12}$ は，東京都 M 市を対象として，それぞれ GIS データから推計した值と実際の延床面積を比較し補正式 を算出しているが，これらは特定地域のサンプルを用い て得られた式であり，本ケーススタディエリアである名 古屋市中心部の建築物にこれらの補正式を適用寸るのは,

表-4 構造種別の仮定

\begin{tabular}{l|l}
\hline 戸建住宅 & 木造 \\
\hline 1〜2 階建ての戸建住宅以外の建築物 & \multirow{2}{*}{ 鉄骨造 } \\
\hline 3〜5 階建てで, かつ建築面積が $150 \mathrm{~m}^{2}$ 以 & \\
下である商業用建築物 & \multirow{2}{*}{$\mathrm{RC}$ 造 } \\
\hline その他の3〜5 3 階建ての建築物 & \\
\hline 6階建て以上の建築物 & \\
\hline
\end{tabular}

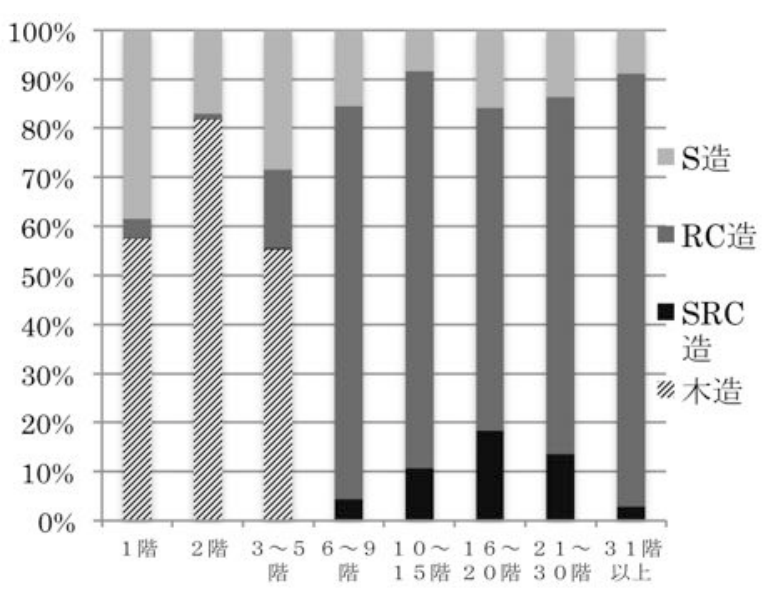

図-3 2007 年度着工建築物の階数別構造割合
妥当性に疑問が残る，よって，本研究では建築面積と階 数の積を延床面積として採用する.

\section{d）構造種別}

構造種別は，木造，鉄骨造， $\mathrm{RC}$ 造の 3 種類に分類し ている. SRC 造の建築物は, 整備されている資材投入 原単位が存在しないため, RC 造として分類した. Zmap や住宅地図には構造種別の記載がない.しかし，現 存していない建物なども含めて全ての建築物に対して 1 棟 1 棟調查を行うことは現実的でないため, 各建築物の 構造種別は建築着工統計 ${ }^{13)}$ を集計した結果から, 表-4 のように仮定し, 分類した. 建築着工統計によると,

2007 年度の日本全国における着工建築物を階数別に集 計すると，6階以上になると RC 造または SRC 造である 建築物の割合が 8 割を超える（図-3）。よって本研究で は 6 階以上の建築物は全て RC 造と仮定したが，大規模 な超高層ビルなどは推計結果に大きく影響を与えること が考えられるため, 公開されている情報や図面などから 構造種別を一棟一棟入力した. 具体的には対象エリア内 で 150 メートルを超える超高層ビルである「ミッドラン ドスクエア」「JR セントラルタワーズ」「スパイラル タワーズ」「ルーセントタワー」の4棟である.

\section{e）用途地域}

国土交通省によって公開されている国土数值情報 ${ }^{14}{ }^{4}$ と, 名古屋市の過去の用途現況図 ${ }^{15}$ 上り, 各年代における用 途地域を入力した.

\section{（3）マテリアルストック・フローの推計方法}

各建築物のマテリアルストックは, 次に示寸式(1)で 推計される.

$$
M S_{s, m}=T F A_{s} \times M I_{s, m}
$$

$M S_{s, m}$ : 建物構造種別 $s$ である建築物の, 建設資材 $m$ の 建設資材ストック

$T F A_{s}$ : 建物構造種別 $s$ である建築物の, 延床面積 $M I_{s, m}$ : 建物構造種別 $s$ である建築物の, 建設資材 $m$ の 資材投入原単位

式(1)中の資材投入原単位は単位延床面積あたりの資 材蓄積量で，本研究では表-5 に示寸東岸ら（2008） ${ }^{10} に$ よって推計された值を使用した。この值は，一般的な木 造, 鉄骨造, RC 造の建築物の図面や写真を元に, 各資 材の蓄積量を推計して, 延床面積で除したものである.

表-5 から分かるように, RC 造の資材投入原単位の值が 他の構造の建築物よりも大きい值となっており, さらに 資材別に見るとコンクリートの值が大きい割合を占めて いる.

また，各年代間で，滅失した建築物，新築した建築物 のみを抽出してマテリアルストックを集計することで, 
その期間でのマテリアルフローを推計することができる. 本研究では，各年代間における建築物の残存・滅失は建 物名称と航空写真による建物形状から判断した。 具体的 には，各年代の航空写真を見比べて明らかに変化してい る場合は，建物名称が変化していなくても更新したと判 断し，逆に航空写真から明らかに同一の建物であること が見て取れる場合は単なる名称変更であり, 更新してい ないと判断した.

表 -5 資材投入原単位

\begin{tabular}{l|r|r|r|r}
\hline $\begin{array}{c}\text { 資材投入原単位量 } \\
\left(\mathrm{kg} / \mathrm{m}^{2}\right)\end{array}$ & \multicolumn{1}{c|}{ 木造 } & \multicolumn{1}{c|}{$\begin{array}{c}\text { 鉄骨造 } \\
(2 \text { 階建て })\end{array}$} & $\begin{array}{c}\text { 鉄骨造 } \\
(3 \text { 階建て })\end{array}$ & \multicolumn{1}{c}{$\mathrm{RC}$ 造 } \\
\hline 砂利・石材 & 78 & 100 & 214 & 138 \\
\hline コンクリート & 221 & 587 & 416 & 2227 \\
\hline モルタル & 3 & 109 & 146 & 44 \\
\hline 木材 & 88 & 20 & 4 & 0 \\
\hline ガラス & 5 & 3 & 1 & 1 \\
\hline 随嗞器 & 52 & 1 & 1 & 3 \\
\hline 鉄 & 7 & 118 & 178 & 97 \\
\hline アルミニウム & 2 & 2 & 1 & 2 \\
\hline その他 & 32 & 22 & 0 & 9 \\
\hline 合計 & 488 & 962 & 961 & 2521 \\
\hline
\end{tabular}

表-6＼cjkstart資材別マテリアルストック（Mt）

\begin{tabular}{l|r|r|r|r|r|r}
\hline & 1970 & 1980 & 1990 & 1997 & 2003 & 2009 \\
\hline 砂利・石材 & 1.12 & 1.47 & 1.80 & 1.82 & 2.33 & 2.65 \\
\hline コンクリート & 10.92 & 17.00 & 22.31 & 23.33 & 31.06 & 36.40 \\
\hline モルタル & 0.66 & 0.74 & 0.84 & 0.80 & 0.95 & 1.05 \\
\hline 木材 & 0.29 & 0.27 & 0.27 & 0.24 & 0.20 & 0.17 \\
\hline ガラス & 0.03 & 0.03 & 0.03 & 0.03 & 0.03 & 0.03 \\
\hline 陶磁器 & 0.13 & 0.13 & 0.15 & 0.14 & 0.13 & 0.12 \\
\hline 鉄 & 0.89 & 1.13 & 1.35 & 1.34 & 1.69 & 1.92 \\
\hline アルミニウム & 0.02 & 0.03 & 0.03 & 0.03 & 0.03 & 0.04 \\
\hline その他 & 0.20 & 0.21 & 0.24 & 0.22 & 0.22 & 0.23 \\
\hline 合計 & 14.26 & 21.01 & 27.02 & 27.94 & 36.64 & 42.60 \\
\hline
\end{tabular}

\section{3. 結果および考察}

\section{（1）マテリアルストックの推計結果}

表-6 に，ケーススタディエリア全域におけるマテリ アルストックの推計結果を示す. マテリアルストックは 一様な増加傾向にあるが，表-1 に示した建築物棟数を 見ると，建築物棟数は減少している期間も見られる．建 物棟数が減少する一方でマテリアルストックが一様に増 加している原因として, 建築物の高層化と, それに伴う 木造の減少，および単位面積あたりの資材投入量の大き い RC 造の増加したことが挙げられる．資材別に見ると， コンクリートのストックが全体の 8 割以上を占めている ことが分かる.

また, 表-7 に各用途地域のマテリアルストック密度 を示す．ここで，マテリアルストック密度とは，各用途 地域で集計したマテリアルストックを，その用途地域の 面積で除したものである. 商業地域におけるマテリアル ストック密度が他の地域に比べて大きく, 他用途地域の 3〜4 倍程度となっている. 商業地域においては, 建築 物の平均階数が高く, $\mathrm{RC}$ 造の割合が大きいため, マテ リアルストック密度が大きくなる. また, 他の用途地域

表-7 用途地域別マテリアルストック密度 $\left(\mathrm{t} / \mathrm{m}^{2}\right)$

\begin{tabular}{l|c|c|c|c|c|c}
\hline & 1970 & 1980 & 1990 & 1997 & 2003 & 2009 \\
\hline 商業地域 & 1.83 & 2.77 & 3.66 & 3.81 & 4.80 & 5.64 \\
\hline 近隣商業地域 & 0.59 & 0.83 & 1.06 & 1.16 & 1.54 & 1.66 \\
\hline 第一種住居地域 & 0.44 & 0.64 & 0.69 & 0.67 & 1.23 & 1.38 \\
\hline 第二種住居地域 & 0.52 & 0.66 & 0.73 & 0.78 & 1.20 & 1.29 \\
\hline 準工業地域 & 0.63 & 0.74 & 0.83 & 0.65 & 1.16 & 1.40 \\
\hline 全体 & 1.19 & 1.76 & 2.26 & 2.34 & 3.06 & 3.56 \\
\hline
\end{tabular}

表-8 用途地域別マテリアルフロー密度 $\left(\mathrm{kg} / \mathrm{m}^{2}\right)$

\begin{tabular}{|c|c|c|c|c|c|c|}
\hline & & $1970 \sim 1980$ & $1980 \sim 1990$ & $1990 \sim 1997$ & $1997 \sim 2003$ & $2003 \sim 2009$ \\
\hline \multirow{3}{*}{ 商業地域 } & 増加量 & 1270.1 & 618.1 & 506.8 & 1083.6 & 884.2 \\
\hline & 減少量 & -255.9 & -167.9 & -151.3 & -600.3 & -303.8 \\
\hline & 蓄積純増 & 1014.2 & 450.2 & 355.5 & 483.2 & 580.4 \\
\hline \multirow{3}{*}{ 近隣商業地域 } & 増加量 & 390.4 & 101.0 & 134.4 & 227.1 & 178.6 \\
\hline & 減少量 & -189.4 & -102.5 & -82.5 & -110.2 & -104.5 \\
\hline & 蓄積純増 & 201.0 & -1.5 & 51.8 & 116.8 & 74.0 \\
\hline \multirow{3}{*}{ 準工業地域 } & 増加量 & 195.7 & 51.3 & 48.7 & 349.1 & 305.7 \\
\hline & 減少量 & -108.8 & -99.0 & -83.1 & -128.5 & -114.3 \\
\hline & 蓄積純増 & 86.9 & -47.7 & -34.4 & 220.6 & 191.5 \\
\hline \multirow{3}{*}{ 第一種住居地域 } & 増加量 & 336.7 & 72.5 & 59.6 & 244.5 & 167.5 \\
\hline & 減少量 & -145.5 & -64.9 & -52.2 & -75.0 & -84.7 \\
\hline & 蓄積純増 & 191.2 & 7.6 & 7.4 & 169.5 & 82.9 \\
\hline \multirow{3}{*}{ 第二種住居地域 } & 増加量 & 190.0 & 62.0 & 59.8 & 114.5 & 62.0 \\
\hline & 減少量 & -60.9 & -53.4 & -50.9 & -80.9 & -30.7 \\
\hline & 蓄積純増 & 129.0 & 8.6 & 8.8 & 33.6 & 31.4 \\
\hline
\end{tabular}




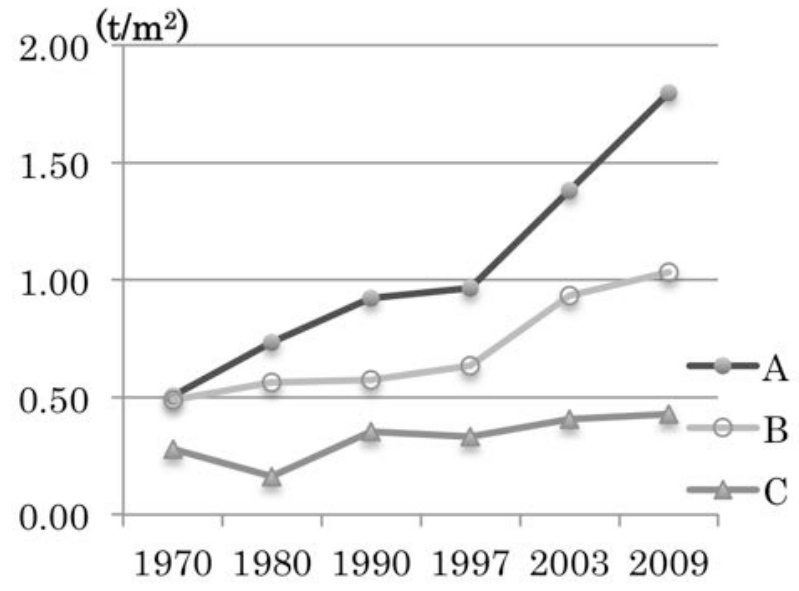

図-4 A， B，Cエリアのマテリアルストック密度

では大差がなく，微小な増加傾向が見られた。

\section{（2）マテリアルフロー密度の推計結果}

表-8 に各用途地域のマテリアルフロー密度を示す. マテリアルフロー密度とは，各年代間でのマテリアルフ ローを用途地域ごとに集計し，それぞれの用途地域の面 積で除したものである. マテリアルフロー密度は，マテ リアルストック密度と同様に商業地域が大きな值を示し ている．商業地域における建築物は，高層でさらに RC 造である割合が大きく，加えて建築年が新しい建築物で その傾向が強い，このことから，商業地域においては資 材の物質代謝が活発に行われていることが分かる.

\section{（3）用途地域の変更によるマテリアルストック密度の}

\section{変化}

用途地域が変更になった $\mathrm{A}$ エリア， $\mathrm{B}$ エリア，Cエリ アにおけるマテリアルストック密度の変化を図-4 に示 す．図-4 から，A エリアのマテリアルストック密度は 増加傾向にあり, 特に 1997 年以降で急激に増加してい る. A エリアでは, 1994 年に商業地域から近隣商業地 域に用途地域が変更された影響で，それ以降の年代で多 くの RC 造の高層マンションが新築された。それによっ て，1997 年以降で急激にマテリアルストック密度が増 加している．Bエリアでは，1994 年に準工業地域から第 二種住居地域に変更され，その後中高層のアパートなど が建てられたことから，1997 年以降に大きく増加して いる. Cエリアでは，住居地域から近隣商業地域に変更 されたものの，建築物の構成に大きな変化は見られず, マテリアルストック密度は緩やかな増加傾向にあった.

$\mathrm{A}$ エリアと $\mathrm{C}$ エリアでは，どちらも近隣商業地域に変 更されたものの，マテリアルストック密度の大きさや変 化率には大きな違いが見られた。これは，同じ近隣商業 地域でも建ぺ率，容積率の指定が異なること，Aエリ アは周囲が商業地域で高層の建築物も多く, 交通アクセ

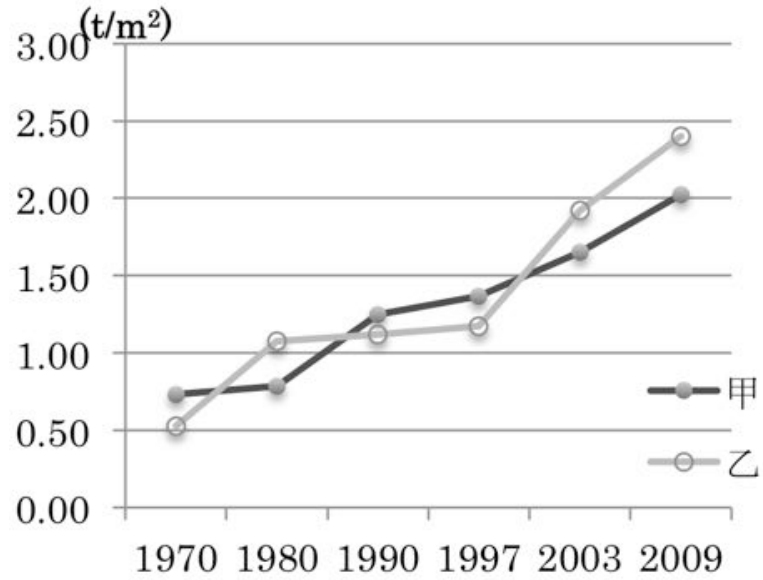

図-5 甲，乙エリアのマテリアルストック密度

スも良いこと，Cエリアは周囲が住宅地域で低層の建築 物の多いエリアであることにより，このような違いが見 られた。

また，大規模市営団地の建設によって都市構造が変化 した甲エリア，乙エリアにおけるマテリアルストック密 度の変化を図-5 に示寸. 図-5 から, 甲エリアと乙エリ アはマテリアルストック密度はどちらも増加傾向にある が，急激に増加するタイミングはずれていることがわか る. 甲エリアでは 1980 年代から 1990 年代にかけて RC 造の市営団地の建設が徐々に進められ，戸建住宅が大幅 に減少した。 それによって，建築物の棟数は減少したが， マテリアルストック密度は 1980 年から 1990 年の間に著 しく増加した。.乙エリアでは, 1960 年代から 1970 年代 にかけて市営住宅の建設による戸建住宅の減少と高層で $\mathrm{RC}$ 造の建築物の増加，さらに 2003 年から 2009 年の間 に団地の一部が建て替えられた。 それぞれの期間で，マ 1テリアルストック密度が大きく増加している.

このように, 都市構造の大きな変化があった場所のみ を抽出して詳細な分析をすることで，行政などによる大 規模な都市の改変がそのエリアにどのように影響を与え るかを，マテリアルストック・フローの観点から分析す ることが可能である.

\section{4. おわりに}

本研究では，名古屋市における 6 年代の 4d-GIS を用 いて詳細なエリアでの MSFA を行った。その結果, 次 のようなことが示された.

・対象エリアではマテリアルストックは年々増加傾向 にあり，2009 年時には 1970 年時の約 3 倍となって いる.

- マテリアルストックの増加要因として, 建築物棟数 の変化ではなく，一棟一棟の高層化に伴う木造の減 
少や $\mathrm{RC}$ 造の増加など, 一棟あたりの延床面積の増 加や構造種別の変化が挙げられる.

・用途地域別にマテリアルストック密度を比較すると, 建築物の平均階数が高いことや, $\mathrm{RC}$ 造の建築物が 多いことから, 商業地域が他の地域と比較して大き い.

・ マテリアルフロー量は, 用途地域別に見るとマテリ アルストック密度と同様に商業地域が他地域よりも 大きな值をとる.

- 商業地域から近隣商業地域に変更された $\mathrm{A}$ エリア では，用途地域の変更により RC 造のマンションが 多く建てられ，マテリアルストック密度が急激に増 加した.

・ 大規模な団地計画のあった甲エリアや乙エリアでは, その影響がマテリアルストック密度に表れた。

1 章で述べたように, 今後都市において物質循環が適 切な状態で保たれるように維持管理を行うためには, 現 状や過去の都市形成の履歴と物質循環の関連を分析する ことが重要である. 今後の課題として, 都市の特性とマ テリアルストック・フローの関連をより深く分析するた めには, 名古屋市以外の都市でも同様の推計を行い, 比 較することが必要である.それにより, 都市の規模や発 展具合などの特徵が物質代謝にどのように影響している かを分析することが可能となる．また，都市の成長の様 子と関連づけるためには, 戦後の復興期まで含むような, より長期間のデータベースを構築し, MSFA を行うこと が必要である.十分長いスパンでのデータベースを使用 することで，建築物の耐用年数などを推計することもで きる.ささら，より多くの種類の建築物に対応できる資 材投入原単位を作成し使用寸ることが必要である. 本研 究のように原単位法を用いて行う推計では, 原単位の值 が結果に大きく影響することから，資材投入原単位の精 緻化が必要である．また，本研究では詳細なエリアの性 質として用途地域を取り上げたが，A エリアと C エリ アのように，同じ用途地域でも過去の変遷や周囲の環境 によってマテリアルストック・フローの大きさや様子が 異なる場合があるため, 今後はより多くの, 都市の特徵 を表寸要素を取り入れた MSFA が必要である.

謝辞: 本研究は, 環境省環境研究総合推進費(1-1402), 日本学術振興科学研究費補助金 (基盤研究(B) 26281056), 文部科学省グリーン・ネットワーク・オブ・エクセレン ス(GRENE)事業の支援により実施された。ここに記して 謝意を表する.

\section{参考文献}

1) 環境省 : 平成 26 年度版 環境・循環型社会・生物多様性白 書, 2014.

2) 谷川寛樹, 山末英嗣, 稲津亮, 前新将: 4D-GIS を用い た都市重量の変化と建設資材の TMR 指標によるリサイク ル性に関する検討, 環境システム研究論文集, Vol.38, pp.413-419, 2010.

3) Hashimoto, S., Tanikawa, H., Moriguchi, Y : Where will large amounts of materials accumulated within the economy go?- A material flow analysis of construction minerals for Japan, Waste Manegement, Vol.27, No.12, 2007.

4) 長岡耕平, 谷川寛樹, 吉田登, 東修, 大西暁生, 石 峰，井村秀文：全国都道府県・政 令都市における建設資 材ストックの集積・分布傾向に関する研究, 環境情報科 学論文集, Vol.23, pp.83-88, 2009.

5) Tanikawa,H. and Hashimoto,S. :Urban stock over time : spatial material stock analysis using 4d-GIS, Building Research \& Information,37 (5), pp.483-502, 2009.

6) 谷川宽樹, 井村秀文 : 都市建設にともなう物質必要量の 定量化と評価に関する研究-住宅地整備のケーススタディー, 土木学会論文集, No.671, pp.35-48, 2001.

7) 青柳淳之介, 杉本賢二, 奥岡桂次郎, 谷川寛樹 : 名古屋 市中心部の 4d-GIS による用途地域ごとのマテリアルスト ック・フロー分析, 第 42 回環境システム研究論文発表会 講演集, pp.1-6, 2014.

8）株式会社ゼンリン：Zmap-TOWNII 1997,2003,2009, 2011.http://www.zenrin.co.jp/product/gis/zmap/zmaptown.htm, 最終 アクセス日 : 2015.03.15

9）株式会社ゼンリン：ゼンリン住宅地図 1990, 1980, 1970.

10）国土地理院 : 地図・空中写真閲覧サービス，2015.3.15閲覧 http://www.gsi.go.jp/index.html

11) 大場亨 : 建築面積及び地上階数からの延べ面積の予測, 「日本都市計画学会学術研究論文集」, 35, 1033-1038, 2000.

12) 阪田知彦, 吉川徹 : 東京都 GIS 建物ポリゴンから推定し た事業所系延べ床面積の補正について, GIS-理論と応用， Vol.10(No.1) 85-94, 2002.

13) 一般財団法人建設物価調査会 : 建築着工統計建築工事価 格データファイル，2009.

14）国土交通省：国土数值情報ダウンロードサービス， 2015.3.15 参照. http://nlftp.mlit.go.jp/ksj/index.html

15) 財団法人名古屋都市センター：名古屋都市計画史 （大正 8 年～昭和 44 年）図集編, 1999.

16) 東岸芳浩, 稲津 亮, 内藤瑞枝, 谷川寛樹, 橋本征二 : 都 市構造物における経年的資材投入原単位の推計に関する 研究, 廃棄物学会研究発表会講演論文集, Vo.19, 2008.

(2015.8.13 受付) 


\title{
A STUDY ON MATERIAL STOCK AND FLOW ANALYSIS OVER TIME USING 4d-GIS IN NAGOYA CITY
}

\author{
Junnosuke AOYAGI, Kenji SUGIMOTO, Keijiro OKUOKA and Hiroki TANIKAWA
}

\begin{abstract}
A large amount of minerals become material flows in and out of urban areas when buildings and infrastructure, such as roads, are constructed and reconstructed. In order to do effective management of materials in a sound material-cycle society, it is necessary to estimate and grasp these material flows. This study describes a comparative MSFA (Material Stock and Flow Analysis) using 4d-GIS in the Nagoya city center for 1970, 1980, 1990, 1997, 2003, and 2009. Material stock in the case study area was found to be increasing, with large material accumulation in the commercial area. Additionaly, it was clarified that changes in the urban structure system has huge impacts on urban metabolism.
\end{abstract}

